\title{
Localization of the genes for tumor necrosis factor and lymphotoxin between the $H L A$ class I and III regions by field inversion gel electrophoresis
}

\author{
J. Ragoussis ${ }^{1}$, K. Bloemer ${ }^{2}$, E.H. Weiss ${ }^{2}$, and A. Ziegler ${ }^{1}$ \\ ${ }^{1}$ Medizinische Klinik und Medizinisch-Naturwissenschaftliches Forschungszentrum, University of Tübingen, Ob dem Himmelreich 7 , Federal \\ Republic of Germany \\ ${ }^{2}$ Institute of Immunology, University of Munich, Goethestrasse 31, D-8000 Munich 2, Federal Republic of Germany
}

The human major histocompatibility ( $H L A)$ complex is located on the short arm of chromosome 6 in the 6p21.31-6p21.33 region (Spring et al. 1985, Ziegler et al. 1985a). The physical length of the entire $H L A$ complex is unknown so far, but our estimate based on the separation of DNA fragments containing $H L A$ genes by pulsed-field gel electrophoresis (Schwartz and Cantor 1984, Carle and Olson 1984) indicates that it encompasses at least 2500 $\mathrm{kb}$ pairs (Ragoussis et al. 1986). This estimate has recently been confirmed (Lawrance et al. 1987). Apart from the highly polymorphic class I and II loci, the $H L A$ complex contains the genes for several complement components and 21-steroid hydroxylase (class III region) (Lamm and Olaisen 1985). In addition, the loci for tumor necrosis factor $(T N F A)$ as well as lymphotoxin (TNFB) are also near or even within the $H L A$ region (Nedwin et al. 1985). Spies and co-workers (1986) demonstrated that the TNF genes map either centromeric to $H L A-D P$ or telomeric to the class II region, although apparently not in the vicinity of any known class I or III genes. The recent demonstration that the TNF loci are situated $70 \mathrm{~kb}$ upstream of the $H-2 D$ gene in the BALB/c mouse between the class III and class I regions (Müller et al. 1987a, b) suggested an analogous location in man, because the genetic organization of the major histocompatibility complexes (MHC) of both species is very similar. To clarify the position of the TNFA and TNFB genes on the HLA map, we have assigned TNFA to large DNA restriction fragments separated by field inversion gel electrophoresis (FIGE) (Carle et al. 1986), which hybridize with either class III- or class Ispecific probes as well. These results prove that the TNFA locus is localized between the $H L A$ class III region and the $H L A-B$ locus.

To avoid interpretative difficulties which might arise from haplotype-specific restriction fragment length polymorphisms, mutant human cell lines with monosomy 6 or HLA hemizygosity were employed. All mutants were derived from BJAB-B95.8.6 lymphoma cells with the $H L A$ haplotypes $A 1, C w 4, B 35$ and $A 2, C-, B 13$ (Spring et al. 1985). Mutant BM 19.7 is a monosomy 6 mutant cell line retaining the $A 2$ haplotype (Ziegler et al. 1985b). BM 28.7 also exhibits monosomy 6 , but with loss of the chromosome bearing the $A 2$ haplotype (Ragoussis et al. 1986). In the interstitial deletion mutant BM 2.2.3, the class I region of the $A 2$ haplotype has been deleted, but the class II and III regions of this haplotype are still present, as is the chromosome 6 carrying the $A I$ haplotype (Ziegler et al. 1985a).

Large genomic DNA fragments were generated with various restriction enzymes, separated by FIGE, and analyzed by hybridization to Southern blots (Southern 1975) under stringent conditions. In the Bss HII digests (Fig. 1), a $370 \mathrm{~kb}$ DNA fragment was detected which hybridized both to the HLA-B locus-specific probe that had been derived $29 \mathrm{~kb} 5^{\prime}$ of the $H L A-B$ gene (Fig. 1b) and to the TNFA probe (Fig. 1c), indicating linkage of TNFA with the $H L A-B$ locus. The class III loci were present on another Bss HII fragment $125 \mathrm{~kb}$ in length (Fig. 1d). The $370 \mathrm{~kb}$ Bss HII fragment did not contain any class I or class II genes (Fig. 1e and not shown).

Hybridizations with the same probes to blots of Nru I-digested DNA (Fig. 2) gave evidence for the linkage of $T N F A$ to the class III genes. Two Nru I fragments of 710 and $690 \mathrm{~kb}$ were detected which contained the class III genes (Fig. 2a and not shown) and TNFA (Fig. 2b). It is likely that partial digestion of an Nru I site is responsible for the generation of two fragments of similar size carrying the class III and TNFA genes. The class I region probes hybridized to a distinct fragment of about $800 \mathrm{~kb}$ (Fig. 2c). An even larger Nru I fragment of more than 1000 $\mathrm{kb}$ carried class II sequences (not shown).

To prove linkage, double digests with Nru I and Bss HII were performed as well (Fig. 3). The hybridization pattern obtained with the class III probes showed that the $125 \mathrm{~kb}$ Bss HII fragment carrying the class III region is contained within the Nru I fragment (Fig. 3a). However, the Bss HII fragment hybridizing with the TNF probe is reduced to a length of only about $50-90 \mathrm{~kb}$ (Fig. 3b). Con- 


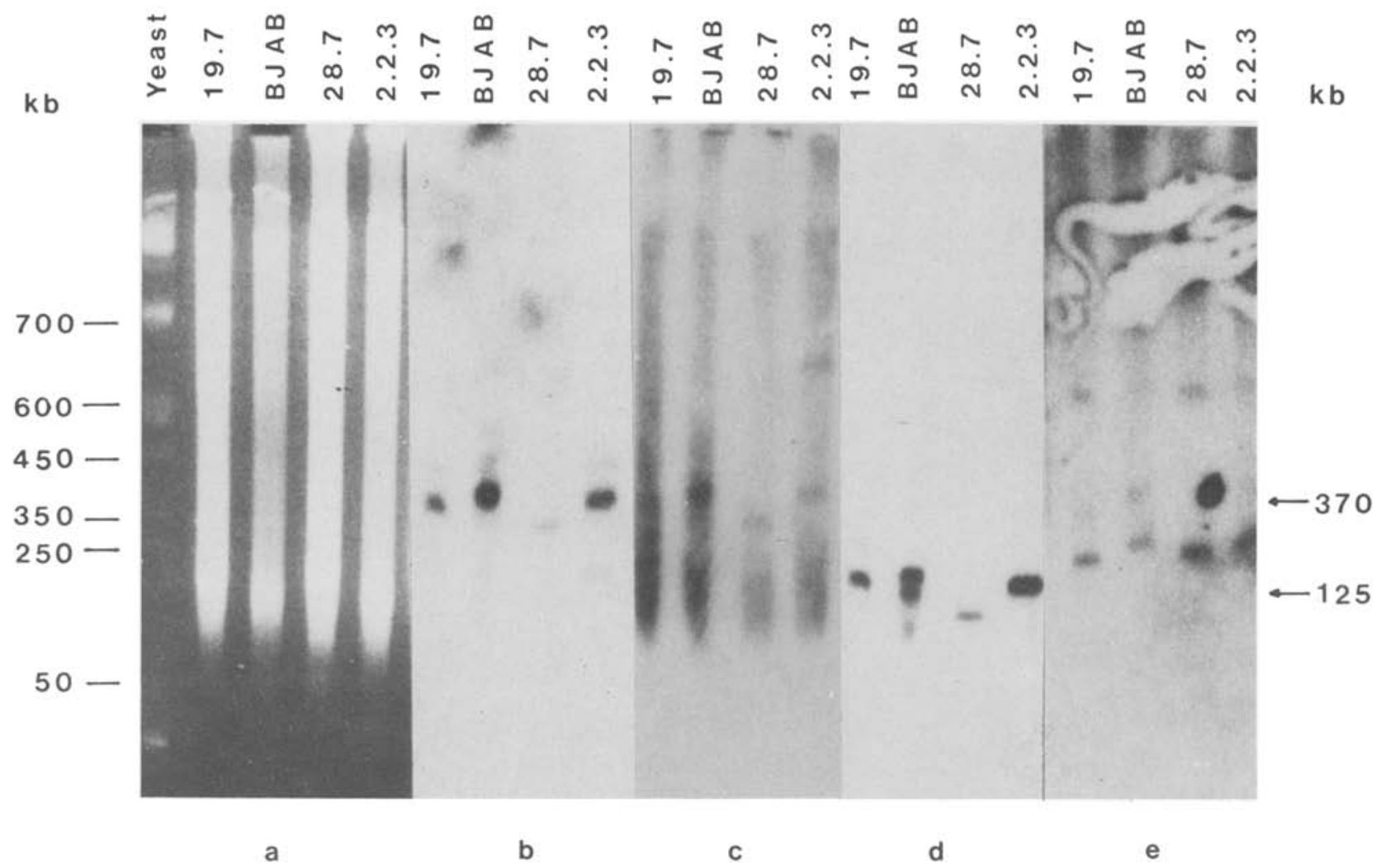

Fig. 1a-e. Southern blot hybridization of human DNA digested with Bss HII. Low melting point (LMP)-agarose blocks containing cells from the cell lines BM19.7, BJAB-B95.8.6, BM28.7, and BM2.2.3 (10 cells per block) were prepared according to the method of van der Bliek and coworkers (1986), slightly modified for FIGE: $2 \times 10^{7}$ cultured cells were pelleted and resuspended in PBS (10 m $M$ sodium phosphate, $150 \mathrm{~m} M$ sodium chloride, $\mathrm{pH}$ 8), pelleted again, and resuspended in $1 \mathrm{ml}$ PBS. One percent of LMP agarose (BRL ultra pure) in PBS was melted, equilibrated at $37^{\circ} \mathrm{C}$, and mixed well with an equal volume of cell suspension. The agarose/cell mixture was poured into a series of slots in a perpex mold. After solidification, the agarose blocks were deposited in a lysis mix $[0.5 \mathrm{M}$ ethylenediaminetetraacetate (EDTA), pH 9.5, $1 \%$ sodium lauryl sarcosine, $1 \mathrm{mg} / \mathrm{ml}$ proteinase $\mathrm{K}]$ at $1 \mathrm{ml}$ per block and incubated for $48 \mathrm{~h}$ at $50^{\circ} \mathrm{C}$. The lysis mix was washed off overnight with TE buffer [10 mM Tris/HCl,

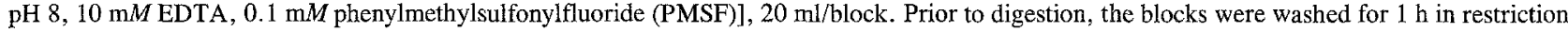
enzyme buffer containing $0.1 \mathrm{~m} M$ PMSF (RE) (10 ml/block). One hundred microliters RE buffer was mixed with 25 units of enzyme in an Eppendorf tube; a $1 / 2$ block was added and incubated for $6 \mathrm{~h}$ at $37^{\circ} \mathrm{C}$. The reaction was stopped with $1 \mathrm{ml}$ TE containing $0.1 \% \mathrm{NaDoSO}_{4}$. Half a block was loaded in a $17 \times 15 \times 0.8 \mathrm{~cm} 1 \%$ agarose gel (Seakem GTG) in $0.25 \times \mathrm{TBE}$ ( $22.5 \mathrm{~m} M$ Tris borate, $0.5 \mathrm{mM}$ EDTA, pH 8 ) and placed in an electrophoresis chamber. FIGE was carried out for $24 \mathrm{~h}$ at $150 \mathrm{~V}$ or $189 \mathrm{~V}$ constant, $15^{\circ} \mathrm{C}$. The voltage gradient was inverted periodically with a time ratio of $3: 1$ and the longer time increasing from 10 to 60 or $120 \mathrm{~s}$. We used a computer-controlled power supply (CS 130, version 2.1) supplied by the EMBL, Heidelberg. After a run, the gel was stained in ethidium bromide $(1 \mu \mathrm{g} / \mathrm{ml})$ for 30 min, destained for 30 min in $\mathrm{H}_{2} \mathrm{O}$, and photographed under $302 \mathrm{~nm}$ UV light (a). The DNA was then blotted to Amersham Hybond membranes, baked for $2 \mathrm{~h}$ at $80^{\circ} \mathrm{C}$, and hybridized sequentially with various DNA probes. Prehybridization and hybridization solutions were as follows: $3 \times \mathrm{SSC}(1 \times \mathrm{SSC}$ is $0.15 \mathrm{M} \mathrm{NaCl} / 0.015 M$ sodium citrate, $\mathrm{pH} 7.4)$ containing $5 \times$ Denhardt's solution $(0.1 \%$ Ficoll, $0.1 \%$ polyvinylpyrrolidone, $0.1 \%$ bovine serum albumin $), 10 \%$ dextran sulfate, $0.5 \%$ NaDodSO, and $100 \mu \mathrm{g} / \mathrm{ml}$ salmon sperm DNA. Prehybridization was performed for $3 \mathrm{~h}$ at $65^{\circ} \mathrm{C}$ and hybridization overnight at $65^{\circ} \mathrm{C}$ with ${ }^{32} \mathrm{P}$ dCTP-labeled DNA probe (Feinberg and Vogelstein 1983) at $10^{6} \mathrm{cpm} / \mathrm{ml}$. Washing was performed in four steps; $10 \mathrm{~min}$ in $2 \times \mathrm{SSC}, 0.1 \%$ $\mathrm{NaDodSO}_{4}$ at room temperature; $30 \mathrm{~min}$ in $1 \times \mathrm{SSC}_{0} 0.1 \% \mathrm{NaDodSO}_{4}$ at $65^{\circ} \mathrm{C} ; 30 \mathrm{~min}$ in $0.3 \times \mathrm{SSC}, 0.1 \% \mathrm{NaDodSO}_{4}$ at $65^{\circ} \mathrm{C}$ and $30 \mathrm{~min}$ in $0.1 \times \mathrm{SSC}, 0.1 \% \mathrm{NaDodSO}_{4}$ at $65^{\circ} \mathrm{C}$. The filters were exposed for $2-7$ days to Kodak XAR $-5 \mathrm{film}$ at $-70^{\circ} \mathrm{C}$. Before rehybridization, the hybridized DNA probe was removed in bidistilled $\mathrm{H}_{2} \mathrm{O}$ at $70^{\circ} \mathrm{C}$ and the result checked by autoradiography. An HLA-B locus-specific probe, a $5.0 \mathrm{~kb}$ Kpn I/Hind III fragment, was isolated which is located $29 \mathrm{~kb} 5^{\prime}$ of the $H L A-B$ gene (Weiss et al. 1987). Another B locus-specific probe, a 2.2 $\mathrm{kb}$ Pst I/Bam HI fragment, was isolated $26 \mathrm{~kb} 3^{\prime}$ of the $B$ gene. Probes for $\mathrm{C} 4$ and $\mathrm{C} 2$ (class III region) were kindly provided by D. Campbell (Belt et al. 1984) and P. Schneider. The TNFA probe was a Hind III/Sal I fragment derived $20 \mathrm{~kb} 5^{\prime}$ of the TNFA gene (Kioussis et al. 1987). As molecular size markers, the yeast strain way 5-4A prepared as described (Schwartz and Cantor 1984) and $\lambda$ concatemers prepared as described (Van Ommen and Verkerk 1986) were used. The HLA-B 5' locus probe detected a $370 \mathrm{~kb}$ fragment (b) which was also recognized by the TNF probe (c) but not by either the C4 (d) or the C2 probe (not shown), which hybridize to a $125 \mathrm{~kb}$ Bss HII fragment, or by the HLA-B $3^{\prime}$ probe, which hybridized to a $270 \mathrm{~kb}$ fragment (e) 


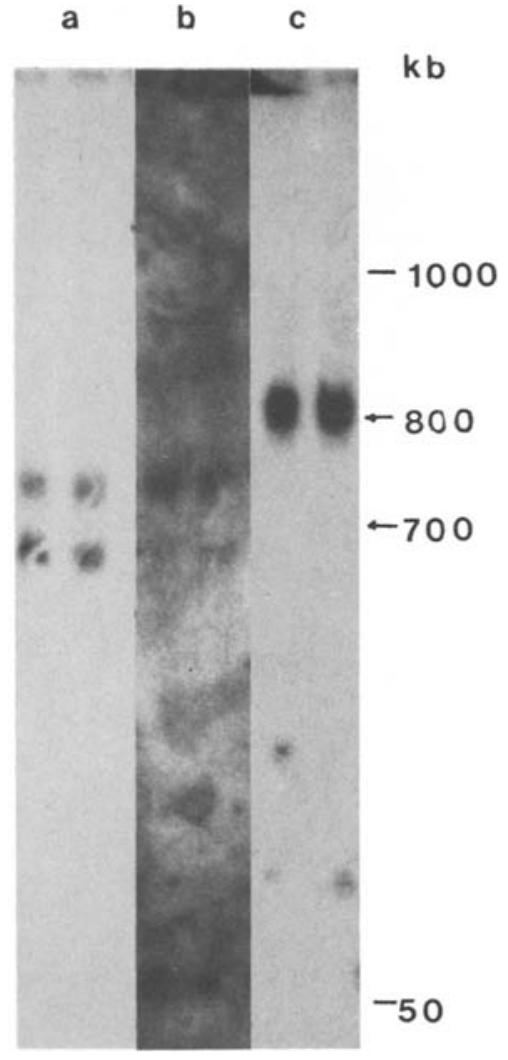

Fig. 2a-c. Southern blot hybridization of human DNA digested with Nru I. DNA from the cell line BM28.7 was digested with Nru I. The conditions for FIGE were as in Figure 1, except that the voltage was increased to $189 \mathrm{~V}$. Southern blotting and hybridization conditions were identical with those employed for Bss HII-digested DNA. The C2 probe detected two bands of slightly larger or smaller sizes than $700 \mathrm{~kb}$ (a) and these were also hybridizing to the TNFA probe (b). The HLA-B5' locus-specific probe detected another fragment of $800 \mathrm{~kb}$ (c) which contains also the $H L A-B$ gene (not shown)

sequently, the HLA-B locus-specific probe was expected to hybridize with a different band of about $300 \mathrm{~kb}$, and indeed, a new band of this approximate size $(280 \mathrm{~kb})$ was found (Fig. 3c). This result proves that the Nru I and Bss HII fragments overlap by $50-90 \mathrm{~kb}$, and the $T N F$ genes must be localized within this region (Fig. 4).

Since an HLA-B gene probe itself and a fragment, isolated $26 \mathrm{~kb} 3^{\prime}$ of this gene, hybridized to a different Bss $\mathrm{HII}$ fragment $(270 \mathrm{~kb})$ (Fig. 1e), it is possible to give a rather precise estimate of the distance between TNFA and $H L A-B$. The TNFA locus and the closely linked

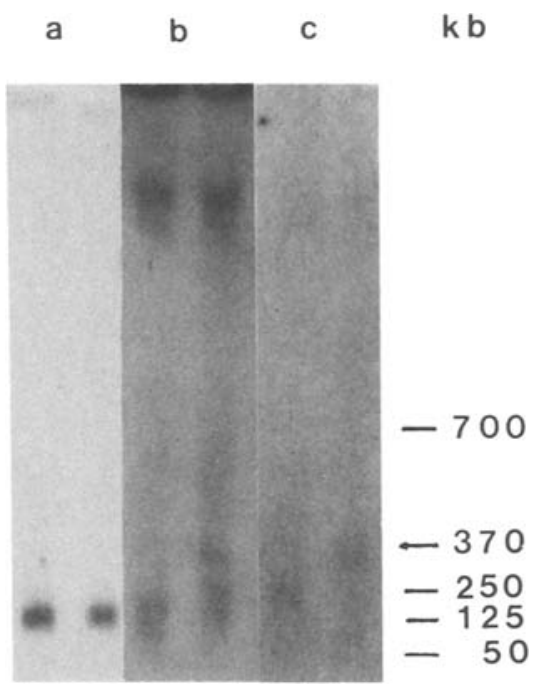

Fig. 3a-c. Southern blot hybridization of human DNA doubly digested with Nru I and Bss HII. DNA from the cell line BM19.7 was doubly digested with Nru I and Bss HII (left) or Bss HII alone (right). FIGE conditions were as in Figure 1 except that the longer time increased linearly from 10 to $120 \mathrm{~s}$. Hybridization was carried out sequentially (as described in Fig. 1) with C4 (a), TNFA (b), and the HLA-B5' locus probe $(\mathbf{c})$

(Nedospasov et al. 1986) TNFB gene are therefore located about $300 \mathrm{~kb}$ centromeric to the $H L A-B$ gene. Preliminary experiments employing double digests with Nru I and Not I indicate a distance of $T N F$ to the class III region of not more than $300-400 \mathrm{~kb}$. Since the TNFA/class III regioncarrying Nru I fragment does not contain class II genes, the minimal distance between the class II loci and the class I region must be about $1000 \mathrm{~kb}$.

These data are in agreement with the mapping of the $T N F$ genes in the mouse, where they are located $70 \mathrm{~kb}$ proximal to the $H-2 D$ gene. However, it is very likely that the physical distance between $H L A-B$ and $T N F$ is considerably larger in the human genome than in the mouse.

Since the association of particular HLA class I and II alleles with a variety of diseases (Tiwari and Terasaki 1985 ) is still an enigma, the mapping of loci in the vicinity of these genes might provide further insight into the underlying mechanisms. Therefore the location of TNFA and TNFB by FIGE or related techniques in the $H L A$ region may contribute to an understanding of $H L A$-disease associations. Since the region occupied by the TNFA and $T N F B$ genes is only about $7 \mathrm{~kb}$ (Nedospasov et al. 1986),
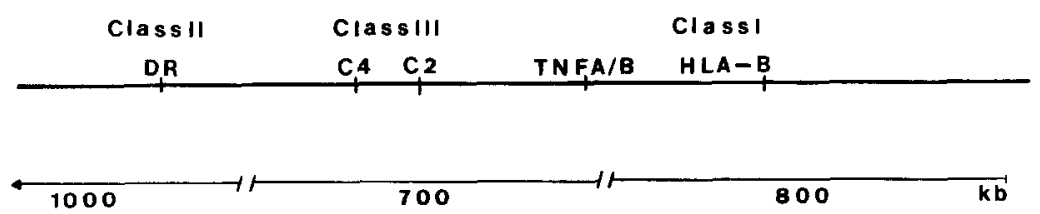

1000

$\frac{700}{125}$

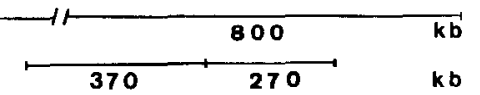

Nrul

BssHII
Fig. 4. Physical map of the central part of the $H L A$ complex based on separation of large DNA restriction fragments by FIGE. $-1 \leftarrow$, the existence of additional Nru I fragments between the ones detected cannot be excluded 
it is to be expected that several additional loci will be found between the class I and III regions. The preparative application of FIGE in conjunction with cloning techniques (Michiels et al. 1987) will help to bridge the long chromosomal distance between the different class I genes and the class III region.

Acknowledgments. This work was supported by the Deutsche Forschungsgemeinschaft through SFB 120 (project A4) and the Genzentrum München. We are grateful to Ms. Andrea Schenk for her valuable technical assistance and to Ms. Gudrun Szalay for her help in the preparation of the molecular size markers. We also thank Dr. Denise Barlow, Mr. Carol Stettner, and Mr. Alfons Riedinger (EMBL, Heidelberg) for help in setting up field inversion gel electrophoresis.

\section{Note added in proof:}

Improved separation conditions in FIGE suggest that the Nru I fragment containing class I genes may be even larger than $800 \mathrm{~kb}$ (Fig. 2c), possibly about $1000 \mathrm{~kb}$.

\section{References}

Belt, K. T., Carroll, M. C., and Porter, R. R.: Multiple forms of human complement component. Cell 36: 907-914, 1984

Carle, G.F. and Olson, M.V.: Separation of chromosomal DNA molecules from yeast by orthogonal-field-alternation gel electrophoresis. Nucleic Acids Res. 12: 5647-5664, 1984

Carle, G. F., Frank, M., and Olson, M. V.: Electrophoretic separations of large DNA molecules in one-dimensional electric fields that are periodically inverted. Science 232: 65-68, 1986

Feinberg, A. P. and Vogelstein, B.: A technique for radiolabeling DNA restriction endonuclease fragments to high specific activity. Anal. Biochem. 132: 6-13, 1983

Kioussis, D., Wilson, F., Daniels, C., Leveton, C., Taverne, J., and Playfair, H. L.: Expression and rescuing of a cloned human tumor necrosis factor gene using an EBV-based shuttle cosmid vector. EMBO J. 6: 355-361, 1987

Lamm, L. U. and Olaisen, B.: Report of the Committee on the Genetic Constitution of Chromosomes 5 and 6 . Eighth International Workshop on Human Gene Mapping. Cytogenet. Cell Genet. 40: $128-155,1985$

Lawrance, S. K., Smith, C. L., Srivastava, R., Cantor, C. R., and Weissman, S. M.: Megabase-scale mapping of the HLA gene complex by pulsed-field gel electrophoresis. Science 235: 1387-1390, 1987

Michiels, F., Burmeister, M., and Lehrach, H.: Derivation of clones close to met by preparative field-inversion gel electrophoresis. Science 236: 1305-1308, 1987

Müller, U., Jongeneel, V., Nedospasov, S. A., Fischer Lindahl, K., and Steinmetz, M.: Tumor necrosis factor and lymphotoxin map close to $\mathrm{H}-2 \mathrm{D}$ in the mouse major histocompatibility complex. $\mathrm{Na}$ ture 325: $265-267,1987$ a
Müller, U., Stephan, D., Philippsen, P., and Steinmetz, M.: Orientation and molecular map position of the complement genes in the mouse MHC. EMBO J. 6: 369-373, 1987b

Nedospasov, S. A., Shakov, A. N., Turetskaya, R.L., Mett, V.A., Azizov, M.M., Georgiev, G.P., Korobko, V.G., Dobrynin, V. N., Filippov, S. A., Bystrov, E. F., Boldyreva, E. F., Chuvpilo, S. A., Chumakov, A. M., Shingarova, L. N., and Ovchinnikov, $Y$. A.: Tandem arrangement of genes coding for tumor necrosis factor (TNF- $\alpha$ ) and lymphotoxin (TNF- $\beta$ ) in the human genome. Cold Spring Harbor Symp. Quant. Biol. 51: 611-624, 1986

Nedwin, G.E., Naylor, S. L., Sakaguchi, A. Y., Smith, D., JarrettNedwin, J., Pennica, D., Goeddel, D. V., and Gray, P. W.: Human lymphotoxin and tumor necrosis factor genes: structure, homology and chromosomal localisation. Nucleic Acids Res. 13: 6361-6373, 1985

Ragoussis, J., van der Bliek, A., Trowsdale, J., and Ziegler, A.: Mapping of HLA genes using pulsed field gradient electrophoresis. FEBS Lett. 204: 1-4, 1986

Schwartz, D. C. and Cantor, C. R.: Separation of yeast chromosomesized DNAs by pulsed field gradient gel electrophoresis. Cell 37 : 67-75, 1984

Southern, E. M.: Detection of specific sequences among DNA fragments separated by gel electrophoresis. J. Mol. Biol. 98: 503-517, 1975

Spies, T., Morton, C. C., Nedospasov, S. A., Fiers, W., Pious, D., and Strominger, J. L.: Genes for the tumor necrosis factors $\alpha$ and $\beta$ are linked to the human major histocompatibility complex. Proc. Natl. Acad. Sci. U.S.A. 83: 8699-8702, 1986

Spring, B., Fonatsch, C., Müller, C., Pawelec, G., Kömpf, J., Wernet, P., and Ziegler, A.: Refinement of $H L A$ gene mapping with induced B-cell line mutants. Immunogenetics 21: 277-291, 1985

Tiwari, L.J. and Terasaki, P. I.: HLA and Disease Associations. Springer Verlag, Berlin, 1985

van der Bliek, A. M., van der Velde-Koerts, T., Ling, V., and Borst, P.: Overexpression and amplification of five genes in a multi-drug resistant Chinese hamster ovary cell line. Mol. Cell. Biol. 6: $1671-1678,1986$

van Ommen, G. J. B. and Verkerk, J. M. H.: Restriction analysis of chromosomal DNA in a size range up to two million base pairs by pulse field gradient electrophoresis. In K. E. Davies (ed.): Human Genetic Diseases: A Practical Approach, pp. 113-133, IRL Press, Oxford, 1986

Weiss, E. H., Bloemer, K., Doerner, C., Kuon, W., Lang, M., Pohla, H., Schattenkirchner, M., and Riethmüller, G.: Molecular biology of the HLA-B27 locus. Brit. J. Rheumatol., in press, 1987

Ziegler, A., Zimmer, F.-J., Fonatsch, C., So, A., and Trowsdale, J.: Mapping of HLA class I and class II genes using HLA deletion mutant cell lines. Eighth International Workshop on Human Gene Mapping. Cytogenet. Cell Genet. 40: 788, 1985a

Ziegler, A., Müller, C., Heinig, J., Radka, S. F., Kömpf, J., and Fonatsch, C.: Monosomy 6 in a human lymphoma cell line induced by selection with a monoclonal antibody. Immunobiology 169 : $455-460,1985 b$

Received July 17, 1987; revised version received September 1, 1987 